\title{
Research Needs: Glass Solar Reflectance and Vinyl Siding
}

R. Hart*, C. Curcija, D. Arasteh, H. Goudey, C. Kohler, S. Selkowitz Lawrence Berkeley National Laboratory 


\section{DISCLAIMER}

This document was prepared as an account of work sponsored by the United States Government. While this document is believed to contain correct information, neither the United States Government nor any agency thereof, nor The Regents of the University of California, nor any of their employees, makes any warranty, express or implied, or assumes any legal responsibility for the accuracy, completeness, or usefulness of any information, apparatus, product, or process disclosed, or represents that its use would not infringe privately owned rights. Reference herein to any specific commercial product, process, or service by its trade name, trademark, manufacturer, or otherwise, does not necessarily constitute or imply its endorsement, recommendation, or favoring by the United States Government or any agency thereof, or The Regents of the University of California. The views and opinions of authors expressed herein do not necessarily state or reflect those of the United States Government or any agency thereof or The Regents of the University of California. 


\title{
Research Needs: Glass Solar Reflectance and Vinyl Siding
}

\author{
Robert Hart*, Charlie Curcija, Dariush Arasteh, Howdy Goudey, Christian Kohler, and Stephen \\ Selkowitz
}

Building Technologies Department, Environmental Energy Technologies Division, Lawrence Berkeley National Laboratory, 1 Cyclotron Road, MS 90R3111, Berkeley, CA 94720

\begin{abstract}
The subject of glass solar reflectance and its contribution to permanent vinyl siding distortion has not been extensively studied, and some phenomena are not yet well understood. This white paper presents what is known regarding the issue and identifies where more research is needed. Three primary topics are discussed: environmental factors that control the transfer of heat to and from the siding surface; vinyl siding properties that may affect heat build-up and permanent distortion; and factors that determine the properties of reflected solar radiation from glass surfaces, including insulating window glass. Further research is needed to fully characterize the conditions associated with siding distortion, the scope of the problem, physical properties of vinyl siding, insulating window glass reflection characteristics, and possible mitigation or prevention strategies.
\end{abstract}

\section{Introduction}

Vinyl siding and insulating windows both have very large market penetration. Vinyl siding has been the most used siding product on new single-family homes in the U.S. every year since 1994. It was applied to $35 \%$ of all new homes built during that time frame. The majority of new vinylsided homes are in the south (40\%), midwest (35\%), and northeast (19\%) (U.S. Census Bureau 2009). Based on sales data and projections from 1999 to 2019, approximately 45\% of residential vinyl siding is, or will be, used in the new construction market; the remainder will be used for retrofits and repairs (Freedonia Group, Inc. 2009).

The U.S. Department of Energy and model energy codes have made improved residential energy efficiency a national priority. Therefore, standards have called for increasingly stringent energy efficiency requirements for windows. The performance levels achieved by insulating windows are mandated by nearly all local building energy codes for both new construction and replacement in existing buildings. Windows are typically designed to meet the requirements of the International Energy Conservation Code (IECC), the most commonly adopted model energy code in the U.S. for residential buildings. To meet IECC's U-factor and solar heat gain coefficient (SHGC) requirements insulating double-pane windows with low-emissivity (low-e) coatings are often used. The popular ENERGY STAR Windows, Doors, and Skylights program typically requires even lower U-factors and SHGCs than the IECC. Common product features used to achieve ENERGY STAR window performance include low-e glass, multiple panes, warm-edge spacers, and gas fills in a sealed volume (ENERGY STAR 2010). Given the existing and projected market penetration of both vinyl

*Corresponding author: Email: rghart@lbl.gov, phone: 510.486.4244 
siding and insulating windows, possible interactions between the two products should be examined and understood.

Recent media reports of permanent vinyl siding distortion on residential buildings have associated reflected energy from insulating window glass as the primary contributor (WFSB 2006, Watson 2010, CBC 2010, WCBV TV 5 2010). (Figure 1a and Figure 1b show examples of permanent vinyl siding distortion on one home.) The exact number of incidents is unknown, and it is unclear whether the representative trade associations or their members are tracking these reports. Many manufacturers in the window, glass, and vinyl siding industries are aware of the issue, and the warranties of all major vinyl siding manufacturers currently exclude damage caused by window reflections. The North Carolina State Building Code Council and the Massachusetts Board of Building Regulations both held public meetings on this issue in 2010. A task group set up by the North Carolina State Building Code Council has considered proposed changes to the state's Residential and Energy Conservation codes in an attempt to address the problem (Noles 2010).

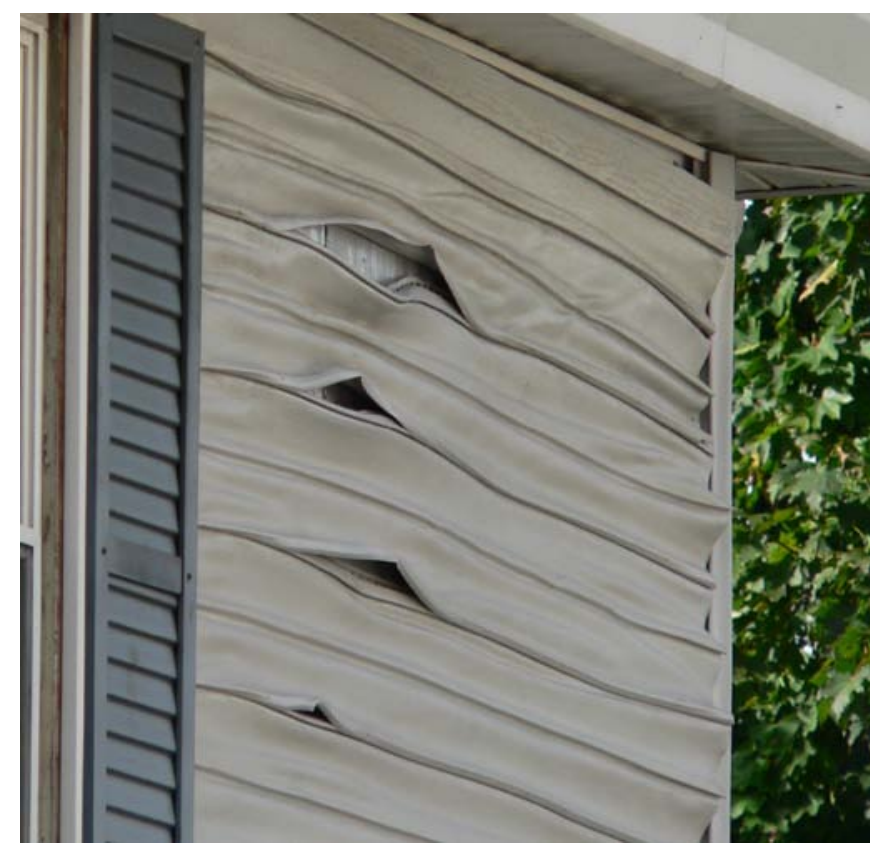

Figure 1a. Vinyl siding with extreme permanent distortion

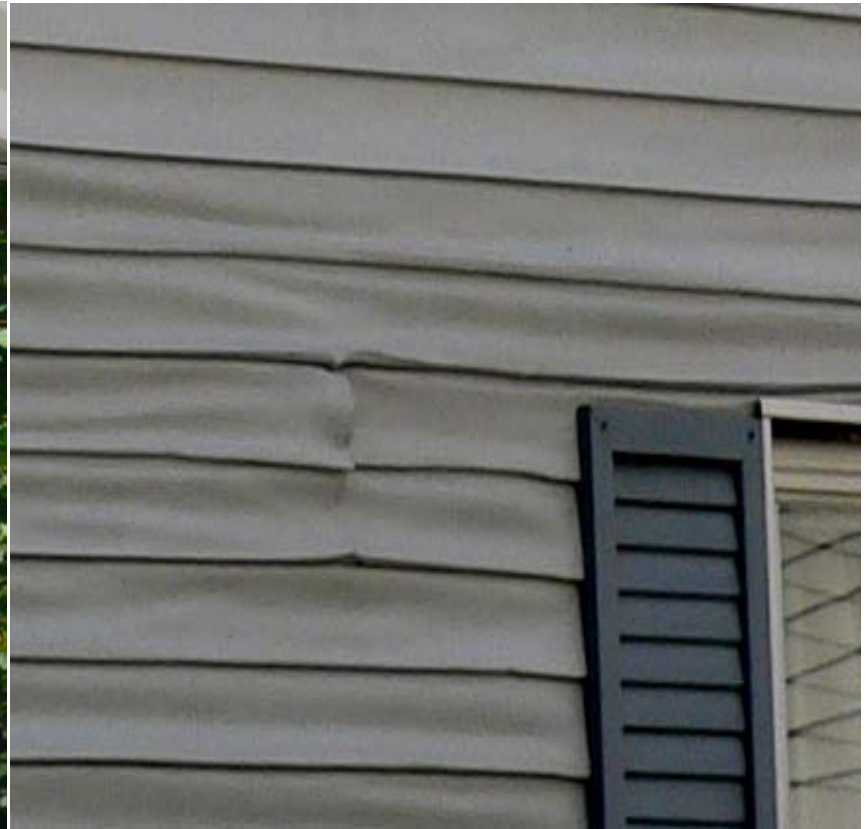

Figure 1b. Vinyl siding with more common, less severe, distortion

\section{Environmental factors}

Environmental conditions play a primary role in heat transfer at the siding surface. Direct solar radiation to siding, reflected solar radiation from nearby surfaces, ambient air temperatures higher than the siding surface, and re-radiated heat from nearby surfaces such as asphalt are primary contributors for siding heat gain from the environment. Re-radiated heat from the siding 
surface, wind speed, and ambient air temperatures lower than the siding surface are primary contributors for siding heat loss to the environment. The siding's equilibrium surface temperature occurs when the heat gained from the environment equals the heat lost to the environment. Under certain circumstances the local equilibrium siding surface temperature can be well above ambient air temperature. Table 1 lists environmental factors that may affect temperature of the siding surface. The factors may not influence temperature rise of the siding surface equally; they are presented in a random order.

Table 1. Environmental factors that may affect temperature of the siding surface

\begin{tabular}{|c|c|}
\hline Factor & Description \\
\hline $\begin{array}{l}\text { Orientation of siding } \\
\text { surface }\end{array}$ & $\begin{array}{l}\text { The sidings view factor (fraction of radiation that leaves one } \\
\text { surface and is intercepted by another surface) of energy sources } \\
\text { and nearby surfaces, and its direction relative to local winds helps } \\
\text { determine the equilibrium temperature reached by the siding } \\
\text { surface. }\end{array}$ \\
\hline $\begin{array}{l}\text { Direct and diffuse solar } \\
\text { radiation }\end{array}$ & $\begin{array}{l}\text { The energy from direct solar and diffuse sky radiation typically } \\
\text { has a large impact on siding surface temperature. The } \\
\text { combination of solar azimuth, solar altitude, and orientation of the } \\
\text { siding surface determine the extent of direct and diffuse solar } \\
\text { exposure. }\end{array}$ \\
\hline Reflected solar radiation & $\begin{array}{l}\text { Direct reflected solar energy from smooth surfaces such as } \\
\text { window glass and swimming pools and diffuse reflections from } \\
\text { rough surfaces such as painted walls, patios, sidewalks, and } \\
\text { driveways may heat the siding surface. }\end{array}$ \\
\hline $\begin{array}{l}\text { Long-wave radiated energy } \\
\text { from nearby surfaces }\end{array}$ & $\begin{array}{l}\text { Re-radiated heat from nearby surfaces, such as asphalt, may } \\
\text { increase the temperature of the siding surface. The heat island } \\
\text { effect is an example of this (LBNL Heat Island Group 2010). }\end{array}$ \\
\hline Physical obstructions & $\begin{array}{l}\text { Objects such as foliage, fences, or adjacent houses may block } \\
\text { direct or reflected solar radiation from reaching the siding } \\
\text { surface. }\end{array}$ \\
\hline Local climate & $\begin{array}{l}\text { Local wind speed and air temperature affect the heat-transfer rate } \\
\text { of the siding surface to the ambient air. }\end{array}$ \\
\hline Architectural design & $\begin{array}{l}\text { Alcoves, overhangs, and other architectural features may block } \\
\text { wind or trap heat near the siding surface. }\end{array}$ \\
\hline Proximity of heat sources & $\begin{array}{l}\text { The distance of the siding from the source of direct or reflected } \\
\text { radiation will help determine the quantity of radiation that } \\
\text { reaches the surface. Air conditioner compressors, barbeque grills, } \\
\text { and other common residential heat sources may heat siding if } \\
\text { located close to the siding surface. }\end{array}$ \\
\hline
\end{tabular}

Direct solar radiation can add significant heat to a surface. The peak solar irradiance in the US for a surface perpendicular to the sun is typically between 250 and 350 BTU/(hr*sq ft) (800-1100 
$\mathrm{W} / \mathrm{m}^{2}$ ) and occurs when the sun is highest in the sky. The solar energy incident on a receiving surface (such as siding or window glass) is highly dependent on the orientation of that surface relative to the sun. As the angle between the sun and the receiving surface increases the effective solar exposure is reduced. This effect can be seen in Figure 2 with the low solar irradiance on a vertical surface at mid-day with high summer sun. Figure 2 shows peak modeled global solar irradiance on a vertical, solar tracking, surface in Golden, $\mathrm{CO}$ on the summer and winter solstices (Bird 1991). The three peak irradiances shown in Figure 2 all occur at a solar altitude (angle above the horizon) of approximately 30 degrees. The solar azimuth (angle in the horizontal plane) at the peaks varies throughout the year, thus the compass orientation of a vertical surface required to reach peak direct irradiance levels also varies, as indicated in the figure. Golden, CO is modeled in Figure 2 as a representative location since it is centrally located in the continental US; the curve shapes and peak irradiances will vary with other locations and sky conditions. Figure 3 illustrates the changes in solar azimuth and altitude with the sun's path across the sky in the Northern hemisphere.

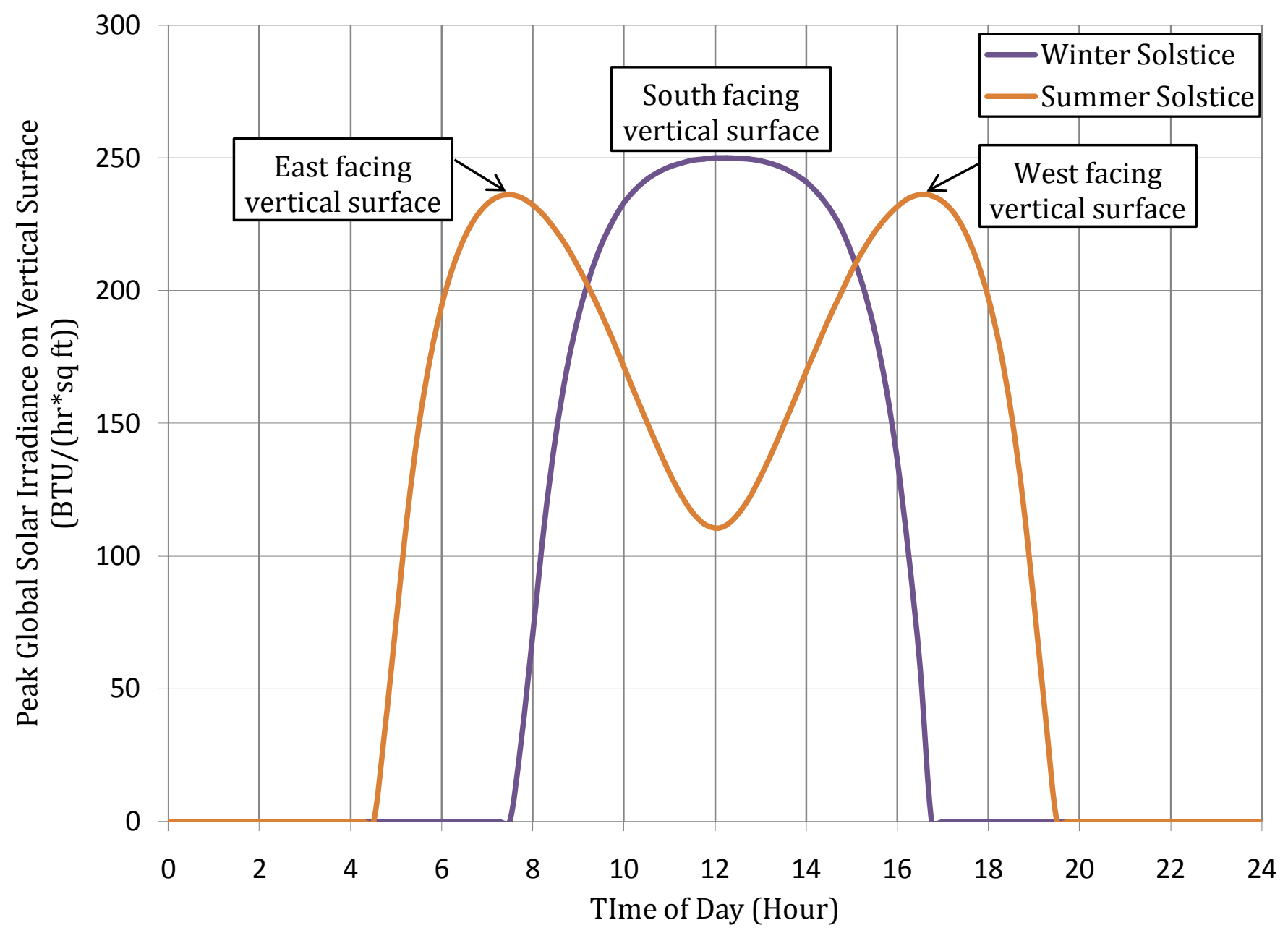

Figure 2. Modeled peak global solar irradiance on a vertical solar tracking surface in Golden, CO. 


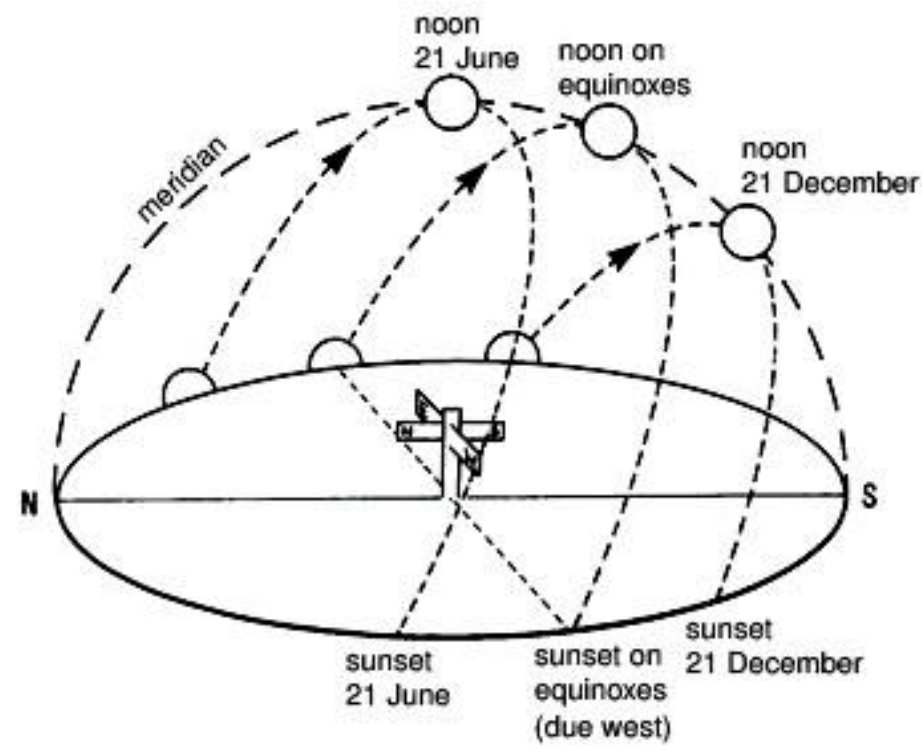

Figure 3. Apparent position of sun in Northern hemisphere (Nuffield Foundation 2009)

A percentage of incident solar energy is reflected from all exposed building materials. For most common building materials, the reflection is effectively diffused in all directions because of optically rough surface characteristics (Reagan and Acklam 1979). However, on smooth surfaces such as window glass, the reflection is direct, and its path is determined by the angle between the line normal to the glass surface and the earth-sun line (a combination of the solar azimuth and solar altitude), called the incident angle $\theta$. Figure 4, Figure 5, and Figure 6 show two-dimensional projections of common residential solar exposure configurations with direct and reflected solar energy on the siding surface. 


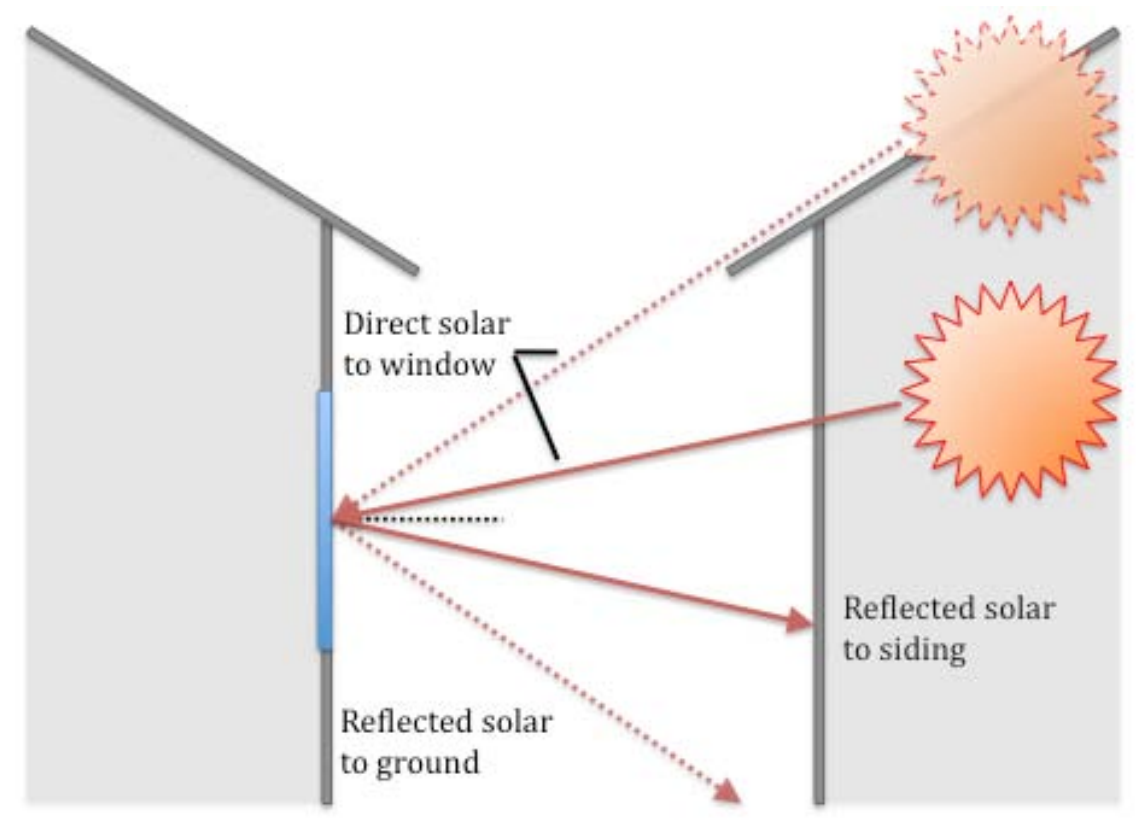

Figure 4. Elevation view of representative solar radiation geometry for neighboring houses

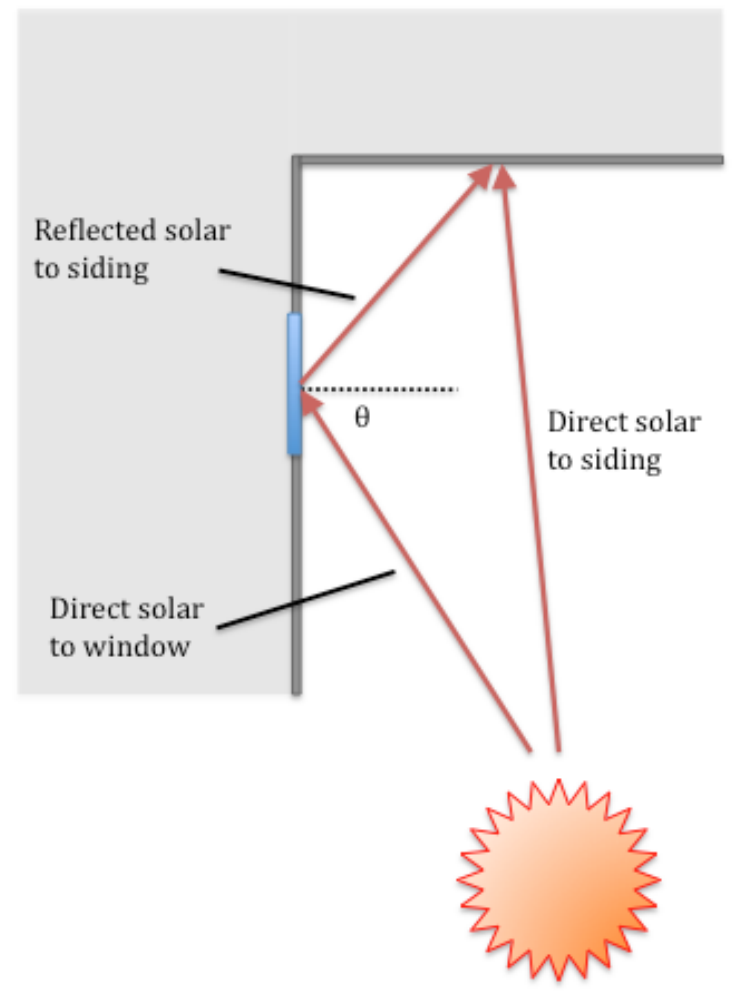

Figure 5. Plan view of solar radiation geometry on perpendicular walls, representative of an alcove.
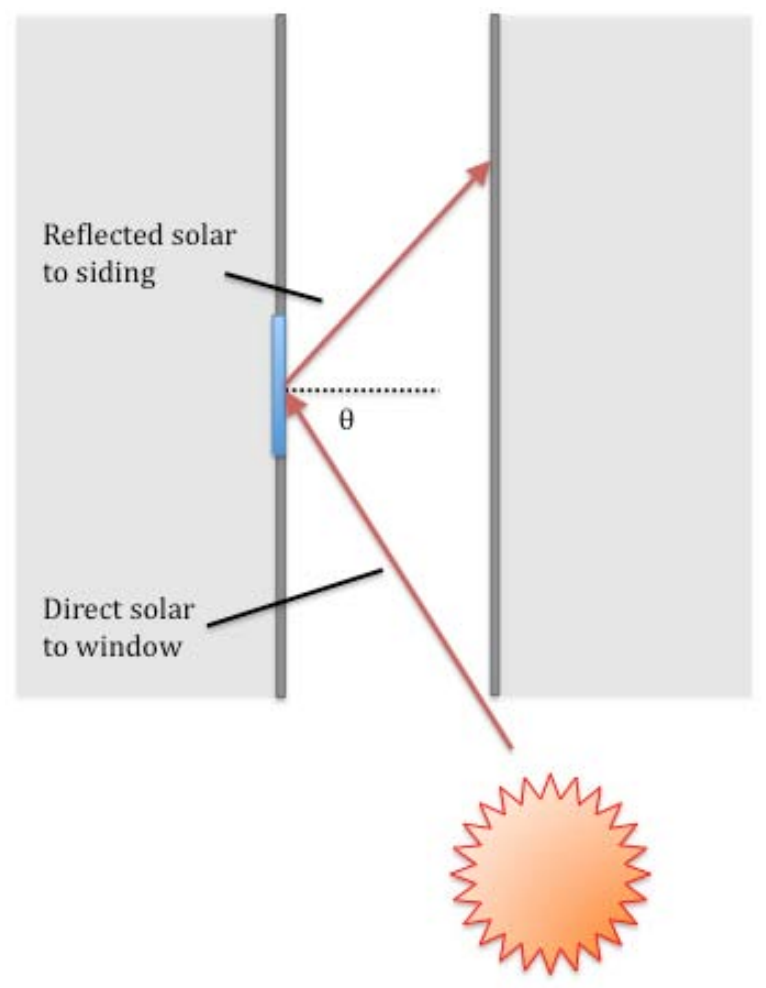

Figure 6. Plan view of solar radiation geometry on parallel walls, representative of neighboring houses. 


\section{Vinyl Siding}

Permanent distortion of vinyl siding from heat build-up may be associated with multiple material properties. Figure 7 shows distorted vinyl siding next to a vinyl window frame with no signs of distortion. The differences in solar absorption, thickness, profile, extrusion process, distortion temperature, and installation may all help explain why the siding is distorted in this case and the window frame is not.

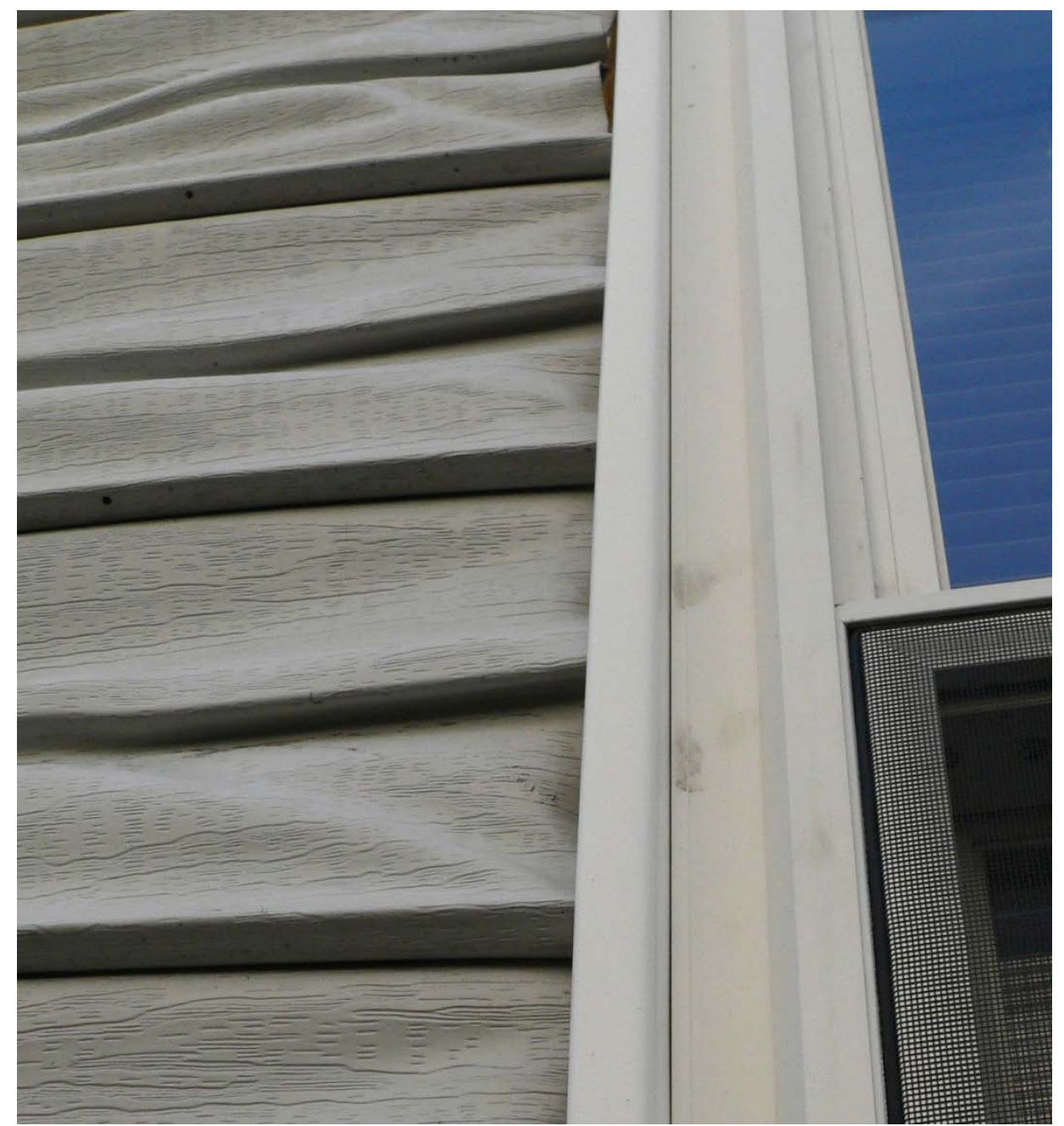

Figure 7. Permanently distorted vinyl siding adjacent to an undistorted vinyl window frame

Approximately forty-five percent of the sun's radiation that typically reaches the earth surface in North America is in the visible spectrum between 0.40 and 0.70 micrometers $(\mu \mathrm{m})$, so an object's absorption in this range is very important to heat build-up (ASTM 1998). A black object absorbs most visible incident solar energy, while a white object reflects most visible energy.

Surface temperature differences of approximately $35^{\circ}$ Fahrenheit (F) $\left(20^{\circ}\right.$ Celsius [C] $)$ have been measured between vertical white and black vinyl in outdoor exposures (Scott 1996, Rabinovitch et 
al. 1983). Figure 8 shows the calculated temperature increase of vertical vinyl samples as a function of solar intensity from a solar exposure study in Arizona. The vertical temperature rise is calculated based on samples tested at 45 degrees from horizontal (Wilkes et al. 2005). The samples used in these tests were specially prepared and cannot be assumed representative of temperature rises in actual vinyl siding. The black sample, in particular, was prepared to maximize solar absorption and serve as a reference point for the maximum achievable vinyl temperature rise. The temperature rise of actual vinyl siding will fall between the white and black extremes when exposed to the same conditions. The slopes of the lines show linear increases of surface temperature with solar intensity within the range studied. As expected, the temperature rise difference between light and dark colors increases as the incident solar energy increases.

Vinyl siding may become slightly lighter or exhibit a slight color shift from weathering, so the relative temperature increases of lab tested samples may not accurately represent aged siding. Vinyl siding is currently measured for color retention in ASTM D6864 and D7251. Although these tests will help estimate the color change in siding that results from weathering, they do not give a correlation with solar absorption or distortion properties of the material.

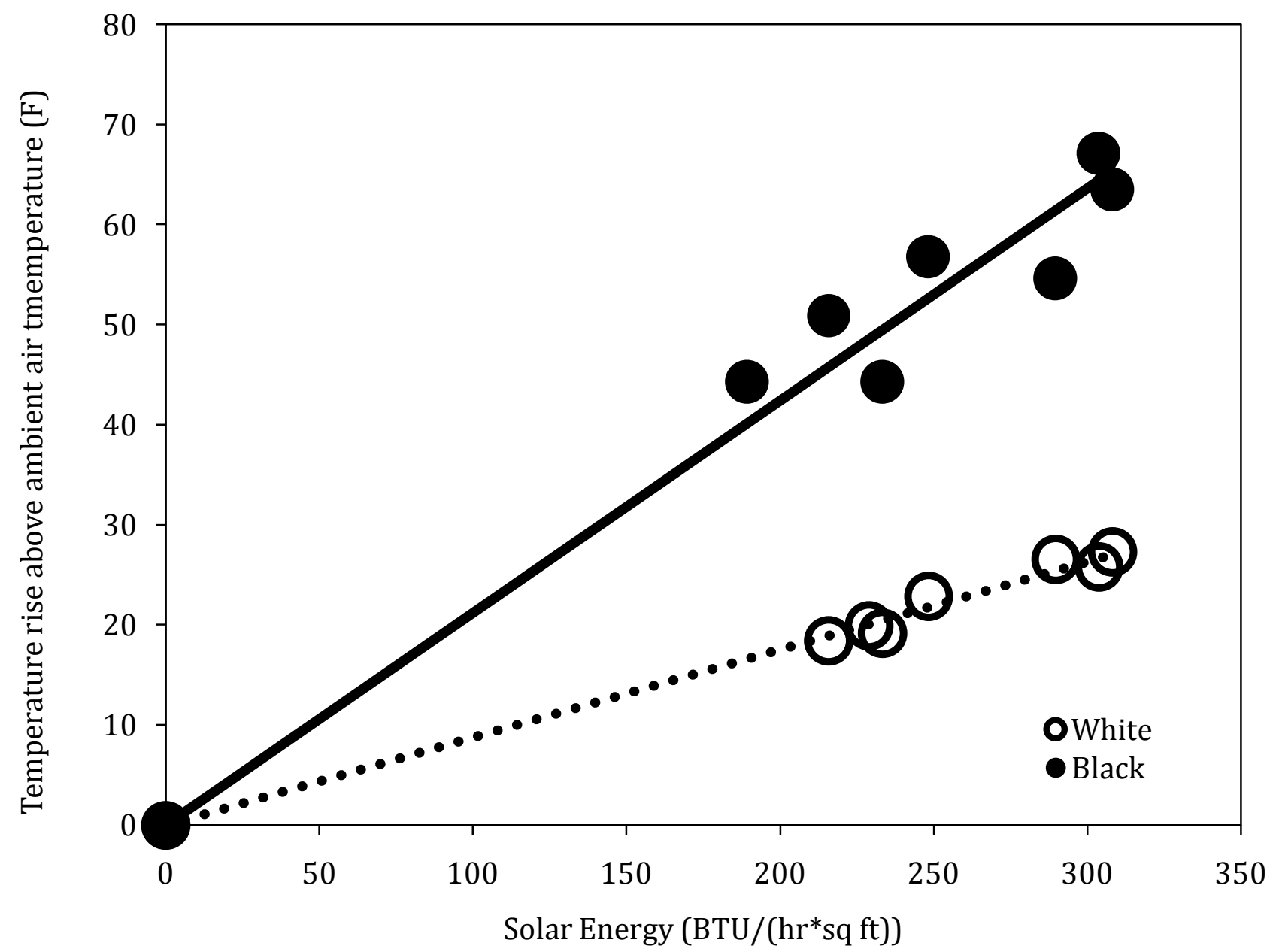

Figure 8. Temperature rise above ambient air temperature for black and white rigid polyvinyl chloride (PVC) (Wilkes et al. 2005). 
The majority, approximately 51\%, of solar energy to which exterior building materials are typically exposed is in the infrared (IR) spectrum (ASTM 1998). Because of this, absorptance in the IR spectrum has the greatest impact on the quantity of solar energy a material absorbs. Carbon black, a common black pigment, absorbs approximately 95\% of solar IR, therefore alternative pigments with more favorable reflectance in the IR range are almost always used in vinyl siding. For comparison, titanium dioxide, an often-used white pigment, absorbs approximately $20 \%$ of solar IR. The color of an object is typically associated with the amount of energy it absorbs, but some companies have developed black pigments with similar absorptance to carbon black in the visible spectrum that achieve $30 \%$ or less absorptance in the IR range. These pigments have been shown through laboratory testing to significantly reduce the temperature rise of black paint, compared to samples using carbon black (Burkhart et al. 2000, Ferro 2007). ASTM D4803 was developed to give relative heat build-up compared to carbon black pigmented vinyl building products under certain defined conditions. The heat source used in the test is heavily weighted in the IR wavelength range so it may not accurately represent the heat build-up in products that make use of IR reflective pigments. The test is not required for vinyl siding compliance in ASTM D3679 and is primarily used for research and development by vinyl manufacturers. The vinyl siding industry reports, and some vinyl siding manufacturers advertise, the widespread use of IR reflective pigments in their siding. The spectral reflectance and potential heat build-up reduction of actual siding products are not published.

The quantity of heat build-up and the effects of elevated temperature on vinyl siding vary based on the physical and chemical properties of each product. The ASTM D3679 specification establishes requirements and test methods for the following aspects of vinyl siding: materials, dimensions, warp, shrinkage, impact strength, expansion, appearance, and windload resistance (ASTM 2009). The thickness and extrusion profile of vinyl siding is in part determined by the need to meet some of these requirements. Typical thickness ranges from 0.035 inches (in.) to 0.050 in. (1.0 millimeter [mm] to $1.3 \mathrm{~mm}$ ). Thicker siding has more mass, which slows heat build-up and provides greater rigidity, although the influence of thickness is unknown when radiation is concentrated over a relatively small area of the siding surface. Some profiles of vinyl siding are deeper, or have bends or channels that increase rigidity. Vinyl siding is also available as insulated siding, which incorporates a rigid insulated backing bonded to the siding that may increase distortion resistance. However, the insulation behind the siding may cause the siding temperature to be higher than if the insulation were not present, which may counteract the increased rigidity. The use and orientation of reflective foil surfaces behind siding have not shown significant contributions to increased siding temperature (Williams 1987).

Temperature rise in nearly all materials, including vinyl siding, results in thermal expansion. Vinyl's coefficient of thermal expansion is relatively high compared to that of other typical siding products, e.g., approximately 10 times that of wood parallel-to-grain (Matweb 2010, USDA 2010). However, properly processed and installed vinyl siding is designed to account for this expansion (ASTM 2006). Permanent distortion may be introduced into properly processed and installed vinyl siding at high temperatures, particularly when unevenly heated across the surface. Improperly processed or installed vinyl siding may be susceptible to a surface distortion known as oil-canning at relatively low temperatures when the temperature rise is uniform or uneven across the surface. Figure 9 shows a typical example of oil-canning with bulges, waves, or ripples on siding caused by the release of latent processing stresses. Oil-canning may be permanent, or 
reversible, when the siding is cooled. ASTM D3679 requires testing of vinyl siding to a minimum of $120^{\circ} \mathrm{F}\left(49^{\circ} \mathrm{C}\right)$ for detection of possible oil-canning. No testing is required above this temperature, so the temperature range at which siding may become susceptible to oil-canning above $120^{\circ} \mathrm{F}$ $\left(49^{\circ} \mathrm{C}\right)$ or other permanent distortion unrelated to oil-canning is not documented.

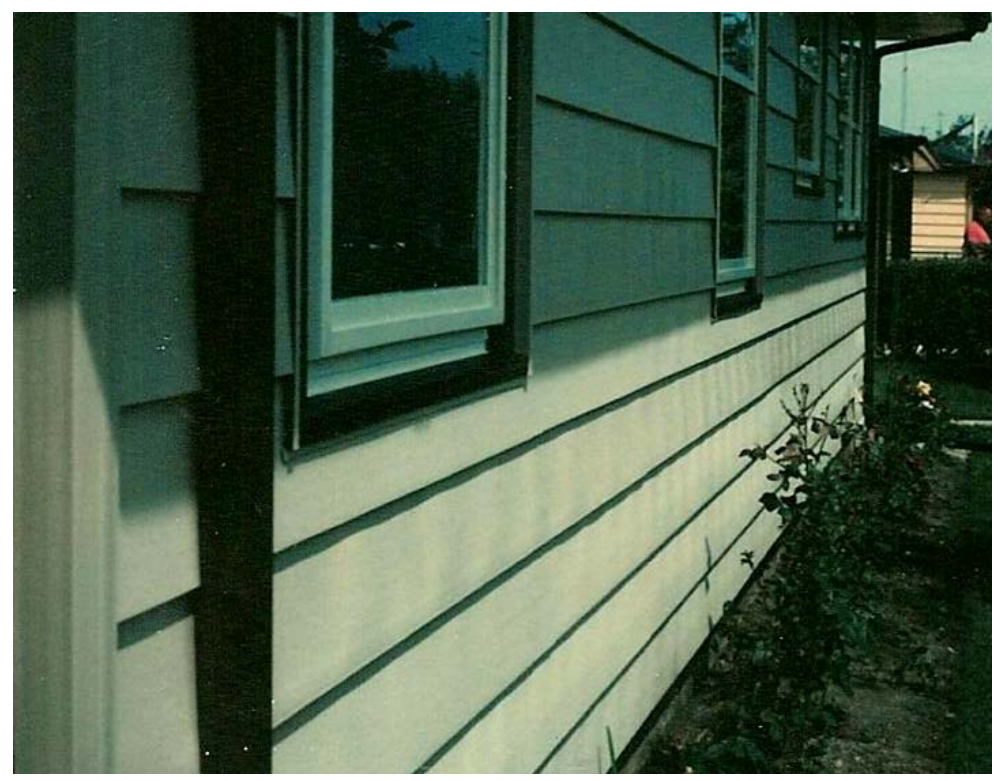

Figure 9. Vinyl siding with characteristic ripples from oil-canning (Summers 2010).

The heat distortion, or deflection, temperature (HDT) of PVC has sometimes been incorrectly used in media reports of vinyl siding distortion as a specific temperature at which vinyl siding may permanently distort. HDT, as tested by ASTM D648, is a measure of a polymer's resistance to distortion under a given load at elevated temperatures. It is important to note that HDT does not represent a specific temperature where distortion will occur. Finished vinyl siding product is subject to different time, temperature, method of loading, and fiber stresses than those in the test method, so the HDT may not predict actual siding behavior (ASTM 2007). Therefore, the HDT should be viewed as a comparative measure and as part of a temperature range in which distortion may occur. The Matweb database lists 62 rigid-grade polyvinyl chloride (PVC) compounds tested to ASTM D648 at 66 pounds per square inch (psi) (0.46 megapascal [MPa]). The measured heat deflection temperatures of these products range from 142 to $192^{\circ} \mathrm{F}$ ( 61 to $89^{\circ} \mathrm{C}$ ) with an average value of $166^{\circ} \mathrm{F}\left(74^{\circ} \mathrm{C}\right.$ ) (Matweb 2010).

If heat build-up is great enough vinyl siding will reach its glass transition temperature. As the siding approaches this temperature it looses its glass like properties and becomes more pliable and susceptible to permanent deformation. The glass transition temperature of vinyl varies widely depending on specific material formulations. The temperature typically ranges from 160 to $200^{\circ} \mathrm{F}$ (70 to $95^{\circ} \mathrm{C}$ ) for most weatherable rigid vinyl compounds. Table 2 summarizes vinyl siding properties that may affect heat build-up and permanent distortion. The factors may not influence heat build-up and permanent distortion of vinyl siding equally; they are presented in a random order. 
Table 2. Vinyl siding properties that may affect heat build-up and permanent distortion

\begin{tabular}{|l|l|}
\hline Property & Description \\
\hline Total solar absorptance & $\begin{array}{l}\text { Generally, darker colors will absorb more energy and have greater } \\
\text { heat build-up. However, even for two materials with the same } \\
\text { apparent color, the heat build-up may vary because of the specific } \\
\text { pigment system used and its absorptance in the IR range. }\end{array}$ \\
\hline Thickness and profile shape & $\begin{array}{l}\text { Thicker siding, as well as certain shapes (deeper profiles with more } \\
\text { bends), may have increased resistance to distortion. }\end{array}$ \\
\hline Rigid insulating backing & $\begin{array}{l}\text { When insulation is formed and bonded to the siding profile it may } \\
\text { increase the siding's rigidity and distortion resistance. Insulation } \\
\text { behind the siding may also increase the siding temperature when } \\
\text { exposed to radiation, which may counteract the increased rigidity. }\end{array}$ \\
\hline $\begin{array}{l}\text { Heat distortion and glass } \\
\text { transition temperatures }\end{array}$ & $\begin{array}{l}\text { The HDT and glass transition temperatures may be used as } \\
\text { reference points for the temperature range in which vinyl siding } \\
\text { may permanently distort. Time of exposure, temperature, method of } \\
\text { loading, and fiber stress all contribute to how and when distortion } \\
\text { will actually occur. }\end{array}$ \\
\hline Durability & $\begin{array}{l}\text { Physical aging, such as from weathering, typically stiffens vinyl } \\
\text { siding and may slightly increase its HDT. The complete effects of } \\
\text { aging on distortion resistance are unknown (Rabinovitch 1992). }\end{array}$ \\
\hline Extrusion process & $\begin{array}{l}\text { Improperly processed vinyl siding may be more susceptible to } \\
\text { distortions such as oil-canning at elevated temperatures. }\end{array}$ \\
\hline Installation & $\begin{array}{l}\text { ASTM D4756 and individual manufacturer installation procedures } \\
\text { are designed to allow for thermal expansion of vinyl siding. } \\
\text { Improper installation, or expansion greater than is allowed for in } \\
\text { installation, may leave the siding more susceptible to, or result in, } \\
\text { permanent distortion. }\end{array}$ \\
\hline
\end{tabular}

At a 2010 Massachusetts Board of Building Regulations and Standards meeting concern was expressed regarding potential damage, including fire dangers, to vinyl siding and other targets of concentrated solar radiation. Damage to other materials found around homes, including house wraps and garbage cans has been reported (Watson 2010, WFSB 2006). These reports are much less common than vinyl siding reports though, in part because they are fewer and/or smaller targets. Auto-ignition temperatures of materials found in and around homes can be used to help determine the potential fire danger from concentrated radiation (Anderson 1970). The autoignition temperature of vinyl siding varies with the specific vinyl compound formulation and test conditions, but is typically reported around $730^{\circ} \mathrm{F}\left(390^{\circ} \mathrm{C}\right)$. For comparison, the auto-ignition temperature of wood, another common siding material, is typically reported in the temperature range of 400 to $500^{\circ} \mathrm{F}\left(200\right.$ to $\left.260^{\circ} \mathrm{C}\right)$ ) (Certainteed 2005, Georgia-Pacific 2009). Vinyl siding will shrink, char, and expose its backing material well before it reaches its auto-ignition temperature. Therefore, if any fire hazards from highly concentrated radiation need to be considered, the focus should be on materials surrounding and backing the vinyl siding, not the siding itself (Dietenberger 1996). 


\section{Insulating Window Glass}

Solar radiation that reflects off window glass is represented by reflectance (the ratio of reflected radiant energy to incident radiant energy). The total solar reflectance of standard clear glass is typically around $13 \%$ of the incident solar radiation. Some low-e coated glass can reach reflectances greater than $50 \%$. Low-e coatings are microscopically thin, virtually invisible, metal or metallic oxide layers deposited on a glass surface primarily to reduce the U-factor (a measurement of heat flow or thermal transmittance) by suppressing radiative heat flow (EWC Glossary 2010). High-solar-gain, low-e coatings are intended to be transparent in the visible and near IR spectrums but reflect low temperature re-radiated long-wave IR radiation. Moderate and low-solar-gain coatings, also known as spectrally selective coatings, are meant to be transparent in the visible and long-wave spectrums and reflect near-IR radiation. Figure 10 shows the spectral reflectance of selected glass types in the visible and near IR ranges. It is important to recognize that reflectance of visible radiation from moderate and low-gain low-e glass is similar to clear glass and the majority of the total reflected solar radiation from these products at normal incidence is in the IR spectrum. Table 3 lists total solar reflectance of typical residential insulating glass units (IGUs).

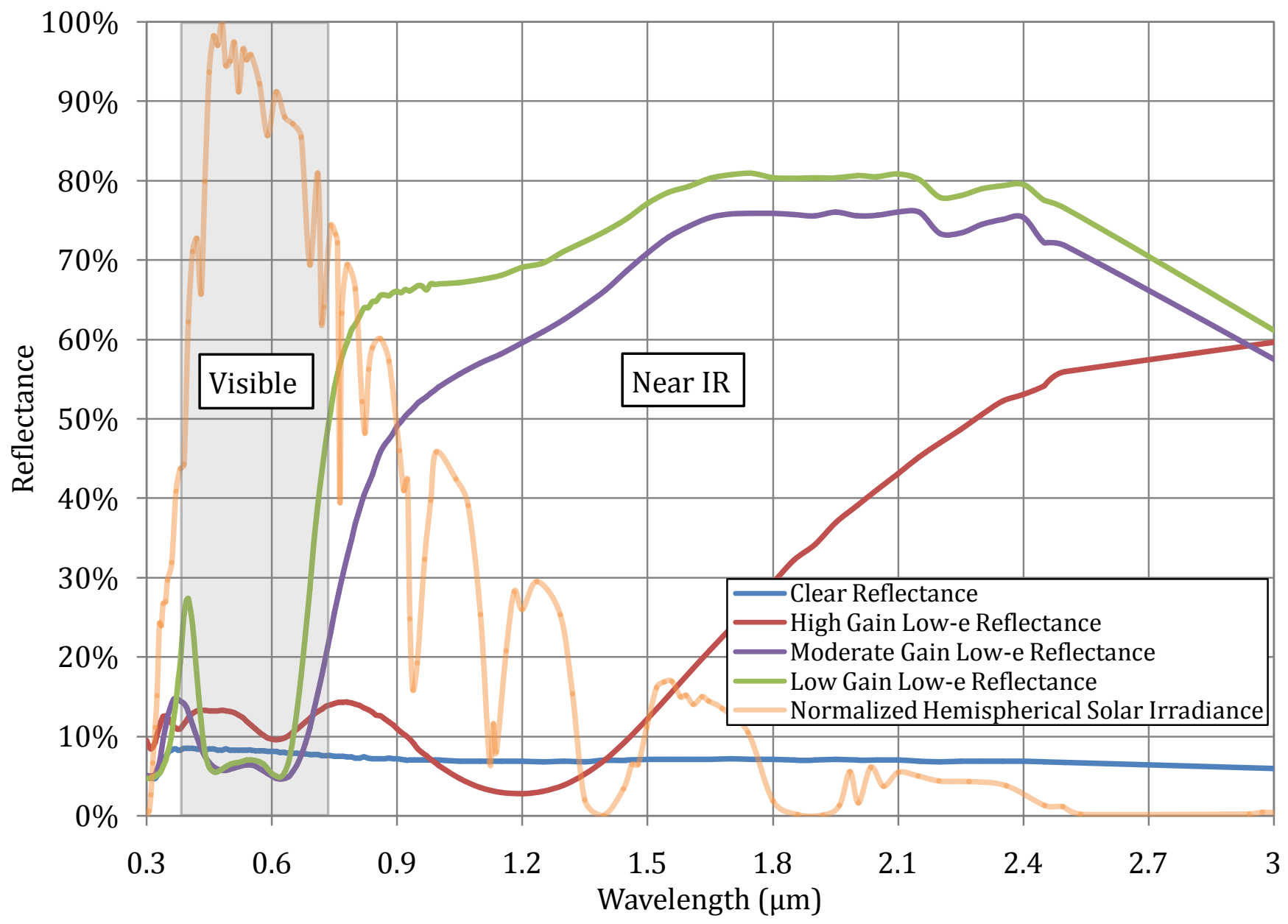

Figure 10. Spectral reflectance of selected glass surfaces. 
Table 3. Typical insulating glass unit total solar reflectance

\begin{tabular}{|l|r|}
\hline \multicolumn{1}{|c|}{ IGU Type } & IGU Total Solar Reflectance Out \\
\hline 2 pane (P), Clear & $13 \%$ \\
\hline 2P, High solar gain, Low-e & $16-25 \%$ \\
\hline 2P, Moderate solar gain Low-e & $35-39 \%$ \\
\hline 2P, Low solar gain Low-e & $42-44 \%$ \\
\hline
\end{tabular}

The reflectances shown in Table 3 and Figure 10 are not accurate for all angles of incidence to the glass surface. As the angle of incidence increases from 0 to 90 degrees (i.e., from perpendicular toward parallel with the glass surface), the reflectance will approach $100 \%$. For angles of incidence up to approximately 40 degrees, the reflectance remains nearly unchanged. At high sun angles, or grazing angles, which are common in alcove configurations such as those depicted in Figure 5, the type of glass has significantly less impact on the reflectance of the IGU. Figure 11 shows the angular dependence of reflectance with selected IGUs.

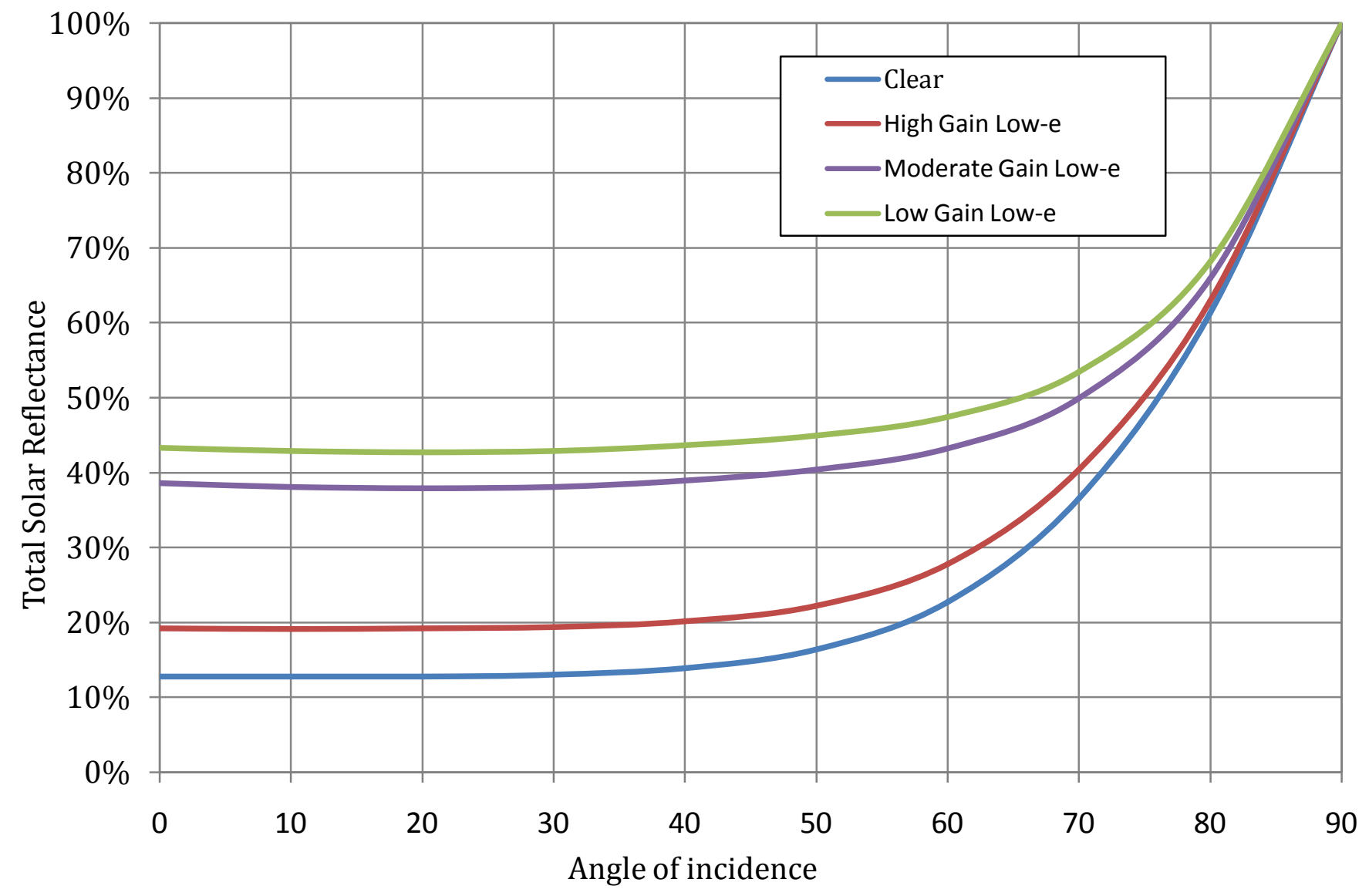

Figure 11. Total solar reflectance of selected IGUs with respect to angle of incidence 
Glass surfaces deflections may concentrate reflected solar energy. Figure 12 illustrates concentrated solar energy from a concave glass surface. Any concavity will concentrate reflected solar energy at a corresponding focal length; the degree of the concavity controls the focal length at which this will occur and the intensity, or area, of the focus. Deflections on the glass surface can be caused by external loading, installation attributes, and internal gap changes in insulating glass units. IGUs are typically constructed with two or more panes of glass separated by a spacer and containing a sealed gas volume. The seal is designed to have very low moisture and gas transmission so that the inside of the unit is essentially a closed system. Environmental conditions affect the pressure balance between the sealed internal volume and the atmosphere. The sealed gas's behavior can be represented by the ideal gas law, so when the gas temperature decreases, the gas volume also decreases; to maintain pressure equilibrium with outside air, the glass will deflect inward (become concave). Glass distortions resulting from environmental conditions such as temperature and barometric pressure are normal and do not necessarily indicate a defective unit. Table 4 lists factors that may cause deflection on the glass surface of IGUs. The factors may not influence deflections on the glass surface equally; they are presented in a random order.

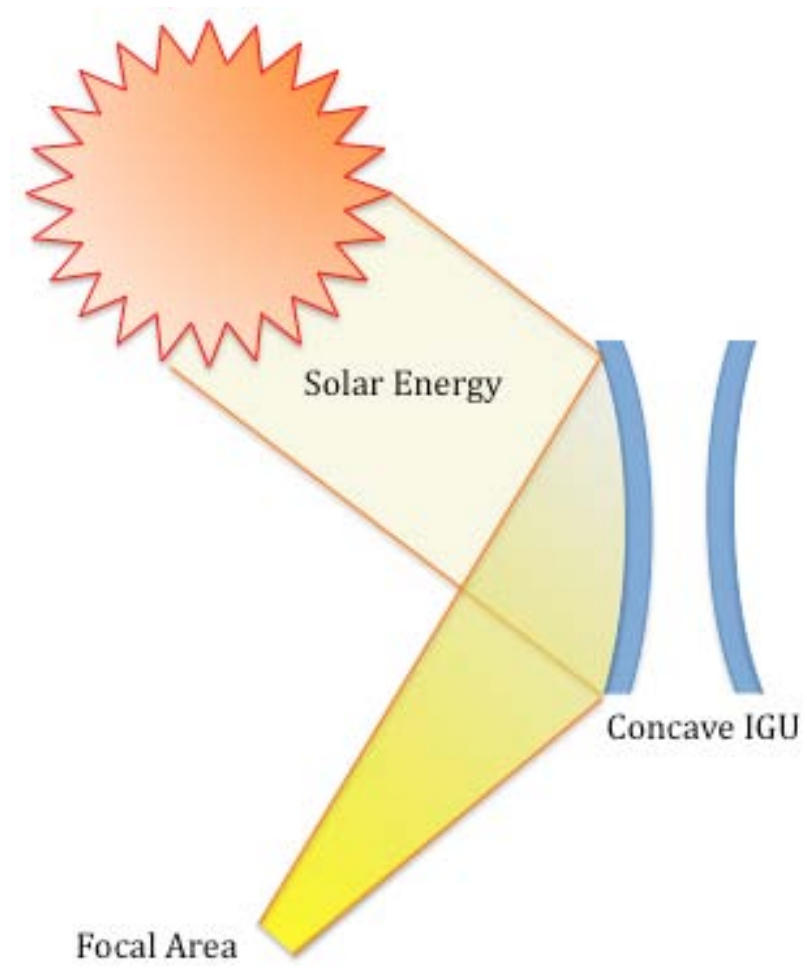

Figure 12. Conceptual illustration of concentrated solar energy from a concave glass surface 
Table 4. Factors that may cause deflections on the glass surface of IGUs

\begin{tabular}{|c|c|}
\hline Factor & Description \\
\hline Pressure differences & $\begin{array}{l}\text { When the external (atmospheric) pressure increases relative to the } \\
\text { interior (sealed) pressure of the unit, e.g., when interior temperature } \\
\text { or altitude decreases or barometric pressure increases, the pressure } \\
\text { differential may cause the glass to deflect inward (become concave). A } \\
1 / 2 \text { psi }(3.4 \text { kilopascal }[\mathrm{kPa}]) \text { pressure differential is approximately } \\
\text { equal to a change of } 20^{\circ} \mathrm{F}\left(11^{\circ} \mathrm{C}\right), 1,000 \mathrm{ft} \text {. }(305 \mathrm{~m}) \text {, or } 1 \text { in. mercury } \\
(\mathrm{Hg})(3.4 \mathrm{kPa}) \text {. }\end{array}$ \\
\hline Manufacturing procedure & $\begin{array}{l}\text { Improper manufacturing by sealing an IGU at an elevated internal gas } \\
\text { temperature when using a heat activated edge sealant may reduce the } \\
\text { amount of gas sealed inside the unit. This will bias the unit toward a } \\
\text { lower internal pressure, which may result in concave glass once the } \\
\text { unit is cooled. }\end{array}$ \\
\hline Gas diffusion & $\begin{array}{l}\text { In argon-filled units the driving force for out-diffusion of argon and } \\
\text { in-diffusion of air is the concentration gradient resulting from using } \\
\text { pure argon in the IGUs sealed volume. Argon diffusion is faster } \\
\text { through most sealant materials than nitrogen and oxygen diffusion is, } \\
\text { so the result with some sealants is a net loss of molecules in the } \\
\text { sealed volume causing a lower internal pressure in the IGU and } \\
\text { inward (concave) glass deflection (Czanderna 2000). }\end{array}$ \\
\hline External pressure & $\begin{array}{l}\text { Wind forces on the exterior pane of glass and internal building } \\
\text { pressures (from air conditioners or ventilation systems) on the } \\
\text { interior pane of glass may both contribute to glass deflection } \\
\text { (Cardinal IG 2008). }\end{array}$ \\
\hline Installation & $\begin{array}{l}\text { Installing windows out of square, plumb, or plane to the wall may } \\
\text { cause deflections in the window frame and on the IGU surface. Frame } \\
\text { joint misalignments or glazing sealant thickness variations may also } \\
\text { cause deflection at the glass edge. }\end{array}$ \\
\hline Glass treatment & $\begin{array}{l}\text { The tempering, or heat treating, of glass may introduce some bowing } \\
\text { that typically appear as waves on the glass surface. }\end{array}$ \\
\hline
\end{tabular}

No industry guidelines currently address an acceptable limit to surface or center-of-glass deflection on installed units, but a requirement does exist for new unglazed units and some recommendations have been made based on visual acceptability of reflected images. Patenaude recommended deflection limits correlated to the short side of the glass (Patenaude 1991). Patenaude's study was based on subjective responses of visual acceptability on commercial glass, so his findings may not apply to visual acceptability in the residential market. National Fenestration Rating Council (NFRC) Program Document 702 includes center-of-glass gap width reduction measurements for NFRC-certified products. The document permits gap width reductions up to $1 / 8$ in. ( $3 \mathrm{~mm}$ ) in units with up to $1 / 2$-in. (13-mm) design gaps, and up to $1 / 4$ in. (6 $\mathrm{mm}$ ) in units with greater than $1 / 2$-in. (13-mm) design gaps. If equal thickness glass is used, then these gap reductions equate to 1/16-in. (1.5-mm) and 1/8-in. (3-mm) glass deflections respectively. A unit's length and width are not taken into account in these measurements. The gap 
reductions permitted in the document apply only to new, finished products at manufacturers' plant ambient temperature and pressure and therefore are not applicable for installed unit inspections (National Fenestration Rating Council 2010). Neither Patenaude's study nor NFRC 702 addresses the effects of gap reduction or glass deflection from a technical or performance perspective, so they cannot be used as guides for acceptable glass deflection when examining solar concentration.

Many models have been used to predict glass surface curvature, from simple spherical mirror calculations to more technical finite-element analysis (FEA) based on thin-plate systems (Chou et al. 1986, Chou et al. 1987). However, these models have not been extensively correlated to deflection shapes seen on installed units. Figure 13 shows a wide variation in IGU reflection shapes from a series of double-hung windows on a house that is approximately $30 \mathrm{ft}$. away from and parallel to the reflecting glass surfaces. As can be seen in the figure, the deflection shapes of IGUs vary widely. The extent and shape of glass deflection is highly dependent on the stiffness of the IGU and the frame to which it is mounted. Table 5 lists factors that may influence the extent and shape of IGU deflection. The factors may not influence the extent and shape of IGU deflection equally; they are presented in a random order.

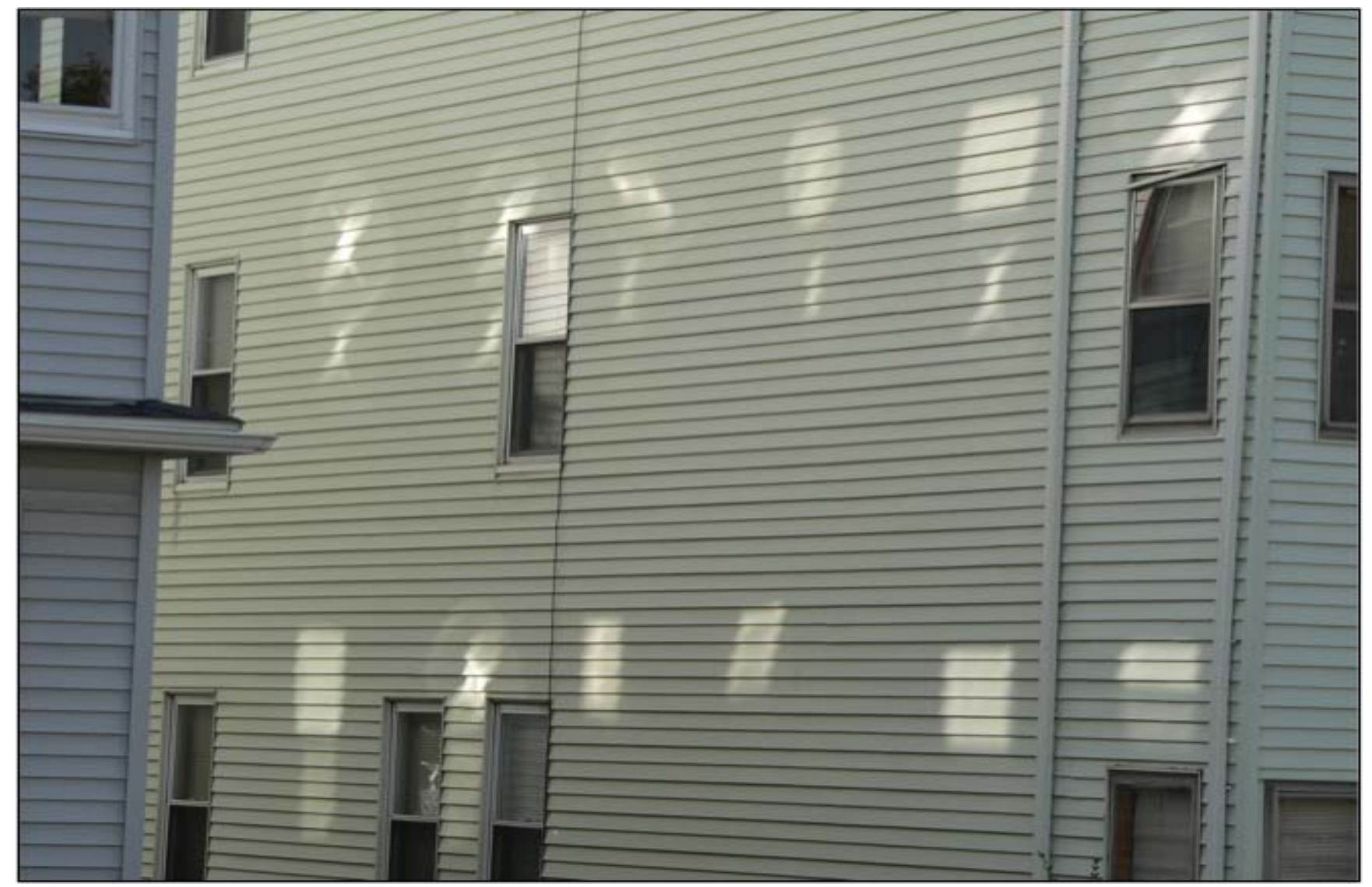

Figure 13. Image of varying IGU reflection shapes from a series of double-hung windows on a house that is $\sim 30 \mathrm{ft}$. away and parallel to the reflecting glass surfaces 
Table 5. Factors that may influence the extent and shape of IGU deflection

\begin{tabular}{|l|l|}
\hline Factor & Description \\
\hline Glass thickness & $\begin{array}{l}\text { Thinner glass deflects more in response to the same force than } \\
\text { thicker glass and can be more difficult to keep flat during } \\
\text { manufacture. Single-strength 2.5-mm (3/32-in.) glass is typically } \\
\text { the thinnest used; double-strength 3-mm (1/8-in.) is also common } \\
\text { in residential windows. }\end{array}$ \\
\hline IGU size and aspect ratio & $\begin{array}{l}\text { ASTM E1300 is typically used by manufacturers to determine the } \\
\text { appropriate glass thickness to use based on area, aspect ratio, edge } \\
\text { support, and load conditions. Higher loads and larger sizes require } \\
\text { thicker or treated glass to meet the same strength and load criteria. }\end{array}$ \\
\hline Glass support & $\begin{array}{l}\text { The extent of unsupported glass edges and the stiffness of the } \\
\text { frame on the supported glass edges both affect deflection. }\end{array}$ \\
\hline Edge configuration & Spacer and sealant stiffness affect edge deflection when under load. \\
\hline Internal gap width & $\begin{array}{l}\text { Larger internal gap widths contain more gas fill, which results in } \\
\text { greater internal pressure differentials from changes in temperature } \\
\text { and altitude. Larger internal gaps also place the glass plates farther } \\
\text { apart, which increases the stiffness of the system. }\end{array}$ \\
\hline
\end{tabular}

\section{Conclusion and Future Research Opportunities}

The environment largely influences equilibrium temperatures on the siding surface. Total heat gained from sources such as solar radiation can be greater than heat losses from modes such as reradiation and convection, resulting in local equilibrium siding surface temperatures well above ambient air temperature. The siding's response to external factors will determine how, and if, distortion will occur. Variations in siding total solar absorptance, thickness, profile, extrusion process, distortion temperature, and installation may all contribute to the siding's response. This paper focuses on solar radiation reflected from insulating window glass; however, other important environmental conditions to consider include solar radiation (both direct and reflected), orientation of the siding surface, local climate, and architectural design.

The spectral reflectance, angle of incidence to the sun, and surface distortion properties of insulating window glass will determine the shape and concentration of reflected solar radiation from the glass. Recent media reports have pointed to these concentrated solar reflections as the primary contributor to vinyl siding distortion; however, all the factors involved in vinyl siding distortion are not yet fully understood. Investigation directly into the causes of vinyl siding distortion has been limited, and a majority of test results from those investigations have been kept confidential by their sponsors. Further studies are needed to fully characterize the conditions associated with siding distortion, the scope of the problem, and possible mitigation or prevention strategies. Table 6 lists proposed research topics and actions to further understand and characterize this issue. Collaboration with industry would be required to develop research protocols and methodologies to address the proposed research topics. 
Table 6. Proposed research topics for vinyl siding distortion

\begin{tabular}{|c|c|}
\hline Research Topic & Objectives \\
\hline $\begin{array}{l}\text { National study of } \\
\text { existing cases }\end{array}$ & $\begin{array}{l}\text { Identify and analyze the scope and trends associated with vinyl siding } \\
\text { distortion. Because large homebuilders account for a significant portion } \\
\text { of new housing construction, collaboration with homebuilder industry } \\
\text { representatives to survey their experiences with this problem would be } \\
\text { beneficial. A study of existing cases in the retrofit market would also be } \\
\text { needed to understand the scope of the issue in that market. The survey } \\
\text { should attempt to capture all contributing factors and the interactions } \\
\text { among them. }\end{array}$ \\
\hline Deflection field survey & $\begin{array}{l}\text { Determine the deflection typically seen in installed IGUs. Perform field } \\
\text { survey of installed windows to determine variances in center-of-glass } \\
\text { deflection. Perform surface mapping of some units to help determine } \\
\text { how surface shape changes in installed units. }\end{array}$ \\
\hline $\begin{array}{l}\text { Vinyl siding (or other } \\
\text { materials of interest) }\end{array}$ & $\begin{array}{l}\text { Determine the siding material properties and environmental factors } \\
\text { that contribute to permanent distortion of vinyl siding exposed to } \\
\text { varying levels solar radiation, and quantify their effects. This basic } \\
\text { outline can also be used as a basis for studying other materials that may } \\
\text { be of interest, including decking, painted wood siding, etc. } \\
\text { - Determine the spectral absorptance for vinyl siding products } \\
\text { using a spectrophotometer and siding samples supplied by } \\
\text { industry. } \\
\text { - Physically test variations in vinyl siding material and construction } \\
\text { properties, including distortion temperature, color, solar } \\
\text { absorptance, wall thickness, and backing type. Siding would be } \\
\text { used as a shine target for reflected solar radiation varying in size, } \\
\text { shape, and intensity. } \\
\text { - Physically test vinyl siding with variations in environmental and } \\
\text { exposure conditions, including exposure frequency and duration, } \\
\text { wind speed, and ambient temperature. } \\
\text { - Determine the temperatures that can be reached on siding from } \\
\text { the cumulative effect of direct, concentrated, and reflecting } \\
\text { sources. }\end{array}$ \\
\hline $\begin{array}{l}\text { Measure reflection } \\
\text { intensity }\end{array}$ & $\begin{array}{l}\text { Determine the influence of various factors on IGU deflection shape and } \\
\text { focal distance. This testing would attempt to quantify the reflected } \\
\text { intensities possible based on ideal deflection of actual IGUs. } \\
\text { - Map the glass surface of deflected IGUs in a laboratory } \\
\text { environment. Units would be tested vertically and deflected by } \\
\text { controlled pressures with a vacuum pump. The mapped surfaces } \\
\text { would be used in ray-trace models to determine the reflected } \\
\text { shape, spectral characteristics, and intensity at various distances } \\
\text { including the focal distance. } \\
\text { - Solar reflections off deflected IGUs would also be measured in a } \\
\text { laboratory environment to verify ray-trace modeling } \\
\text { assumptions. }\end{array}$ \\
\hline
\end{tabular}




\begin{tabular}{|l|l|}
\hline Deflection of IGUs. & $\begin{array}{l}\text { Determine the factors that have the largest influence on deflection } \\
\text { shape, and investigate numerical models that can accurately predict } \\
\text { glass deflection. } \\
\text { - Test variations in frame mount type, frame material, exterior } \\
\text { temperature, and pressure differential across unit. Also include } \\
\text { IGU size and shape, gap width, number of glass panes, glass } \\
\text { thickness, coating, and spacer type. } \\
\text { - Investigate additional factors such as manufacturability of IGUs } \\
\text { with various glass thicknesses, deflection due to "hot sealing," and } \\
\text { argon diffusion. } \\
\text { - Investigate installation variables and acceptable tolerances for } \\
\text { plumb and level. } \\
\text { - Review current numerical models for glass deflection and } \\
\text { determine their strengths and weaknesses. }\end{array}$ \\
\hline Reflection path & $\begin{array}{l}\text { Develop quick assessment tool for designers and/or researchers to } \\
\text { predict solar reflection patterns on siding surfaces. Tool could be used } \\
\text { in the design phase for preventing distortion, or to assist in determining } \\
\text { whether windows contributed to distortion in existing siding distortion } \\
\text { occurrences and aid in optimizing placement of mitigation strategies. } \\
\text { Variables should include geographic position, elevation of surfaces, } \\
\text { solar orientation of reflecting and receiving surfaces, time, obstructions } \\
\text { (roofs, fences, etc.), and reflections from adjacent surfaces (driveways, } \\
\text { walls, etc.). Optional variables could include solar intensity of } \\
\text { reflections, reflections from multiple sources, or other relevant factors } \\
\text { as determined by testing. The tool would use solar position models } \\
\text { developed by others. }\end{array}$ \\
\hline
\end{tabular}

\section{Acknowledgments}

The authors gratefully acknowledge the extensive comments and feedback provided by a wide variety of individuals, companies, and associations within the glass, window, and siding industries. This work was supported by the Assistant Secretary for Energy Efficiency and Renewable Energy, Building Technologies Program, of the U.S. Department of Energy under Contract No. DE-AC0205CH11231. 


\section{Works Cited}

Anderson, H. E. 1970. "Forest Fuel Ignitibility." Fire Technology, Vol. 6, No. 4: 312-319.

ASTM International (ASTM). 2010. Standard D4803: Standard Test Method for Predicting Heat Buildup in PVC Building Products. West Conshohocken PA: ASTM International.

ASTM. 2009. Standard D3679: Standard Specification for Rigid Poly(Vinyl Chloride) (PVC) Siding. West Conshohocken PA: ASTM International.

ASTM. 2006. Standard D4756: Standard Practice for the Installation if Rigid Poly(Vinyl Chloride) (PVC) Siding and Soffit. West Conshohocken PA: ASTM International.

ASTM. 2007. Standard D648: Standard Test Method for Deflection Temperature of Plastics Under Flexural Load in the Edgewise Position. West Conshohocken PA: ASTM International.

ASTM. 1998. Standard G159: Standard Tables for References Solar Spectral Irradiance at Air Mass 1.5: Direct Normal and Hemispherical for a $37^{\circ}$ Tilted Surface. West Conshohocken PA: ASTM International.

Bird, R.E. and R.L Hulstrom. 1991. "A Simplified Clear Sky model for Direct and Diffuse Insolation on Horizontal Surfaces". Technical Report SERI/TR-642-761, Solar Energy Research Institute, Golden, CO.

Burkhart, G., T. Detrie, and D. Swiler. 2000. "When Black is White." Paint \& Coatings Industry. Cardinal IG. 2008. “Distortion in Glass Products.” Technical Service Bulletin \#IG18-05/08.

CBC. 2010. "Melting Vinyl Siding Vexes Homeowners." November 22. http://www.cbc.ca/canada/calgary/story/2010/11/22/calgary-siding-melting-vinylsunlight.html.

Certainteed. 2005. "PVC Capstock on PVC Substrate." Material Safety Data Sheet MSDS Number: CT 10083-1. September 29.

Chou, G. D., C. V. Girija Vallabhan, and J. E. Minor. 1987. A Mathematical Model for Structurally Glazed Insulating Glass Units. Lubbock TX: Glass Research and Testing Laboratory, Texas Tech University.

Chou, G. D., J. E. Minor, and C. V. Girija Vallabhan. 1986. IG Unit Load Sharing Relationships. Lubbock TX: Glass Research and Testing Laboratory, Texas Tech University.

Czanderna, A. W. 2000. Seal Durability in Insulating Glass Units: Summary of Technical Issues and Recommendations to the Depatment of Energy. Ed. R. Anderson and J. R. Pitts. Golden CO: National Renewable Energy Laboratory (NREL), December.

Dietenberger, M. A. 1996. "Ignitability Analysis of Siding Materials Using Modified Protocol for Lift Apparatus." Fire and Materials. Vol. 20: 115-121.

ENERGY STAR. 2010. Anatomy of an Energy-Efficient Window. http://www.energystar.gov/index.cfm?c=windows_doors.pr_anat_window.

EWC Glossary. 2010. http://www.efficientwindows.org/glossary.cfm.

Ferro. 2007. "Cool Colors and Eclipse." Technical Information PSO2. March. 
Freedonia Group, Inc. 2009. "Vinyl Siding Demand (million squares) 1999 - 2019.”

Georgia-Pacific. 2009. "Wood Products." Material Safety Data Sheet ID: GP-31B.

LBNL Heat Island Group. 2010. http://eetd.lbl.gov/HeatIsland/.

Matweb. 2010. “Overview of materials for PVC, Rigid Grade." http://www.matweb.com/.

National Fenestration Rating Council. 2010. NFRC-702-2010E0A0.

Noles, C. 2010. "Agenda for the December 13-14, 2010 NC Building Code Council Meeting." ncdoi. November 11. http://www.ncdoi.com/OSFM/Engineering/BCC/Documents/Agendas/1012.pdf.

Nuffield Foundation. 2009. Observing the motion of the sun.

http://www.practicalphysics.org/go/Experiment_773.html.

Patenaude, A. 1991. “Distortion in Sealed Glazing Units.” Progressive Architecture. October.

Rabinovitch, E. B., J. G. Quisenberry, and J. W. Summers. 1983. "Predicting Heat Buildup Due to the Sun's Energy." Journal of Vinyl Technology, No. 3-Vol. 5: 110-115.

Rabinovitch, E. B. and J. W. Summers. 1992. "The Effect of Physical Aging on Properties of Rigid Polyvinyl Chloride." Journal of Vinyl Technology, No. 3-Vol. 14: 126-130.

Reagan, J.A., and D. M. Acklam. 1979. "Solar Reflectivity of Common Building Materials and its Influence on the Roof Heat Gain of Typical Southwestern U.S.A. Residences." Energy and Buildings, 1979: 237-248.

Scott, K. P. 1996. "Accelerated Weathering Test Correlation Study." Atlas Sun Spots, Issue 53Volume 26: 1-5.

Summers, James, Elvira Rabinovitch, and Ronald Kaminski. 2010. "Factors Considered in Dark Colored Windows and Siding - Part I - The Complex Combination of Required Vinyl Properties" ANTEC 2010 - Proceedings of the 68th Annual Technical Conference \& Exhibition , Orlando, FL, June 16-20. Society of Plastics Engineers: 1875-1880.

U.S. Census Bureau. 2009. Characteristics of New Single-Family Homes Completed. http://www.census.gov/const/C25Ann/sftotalexwallmat.pdf.

United States Department of Agriculture (USDA), Forest Service Forest Products Laboratory. 2010. Wood handbook - Wood as an engineering material. Madison WI: USDA.

Watson, S. 2010. "Melting vinyl siding tied to energy efficient windows." WCNC TV. February 4. http://www.wcnc.com/on-tv/Melting-Vinyl-Siding-tied-to-energy-efficient-windows83583357.html.

WCBV TV 5. Energy Efficient Windows Melt Vinyl Siding. 2010. July 21. http://www.thebostonchannel.com/r/24342726/detail.html.

WFSB. 2006. “New Siding Causes Man's Home To Melt. September 5. http://www.wfsb.com/news/9792847/detail.html.

Wilkes, C. E., J. W. Summers, and C. A. Daniels. 2005. PVC Handbook. Cincinnati, Ohio: Hanser Gardner Publications, Inc..

Williams, J. B. 1987. “Effect of Wall Insulation on Siding Temperatures - I." Mastic. June 5. 


\section{Acronyms and Abbreviations}

$\begin{array}{ll}\text { BTU } & \text { British thermal unit } \\ \text { C } & \text { Celsius } \\ \text { CPVC } & \text { chlorinated polyvinyl chloride } \\ \text { EWC } & \text { Efficient Windows Collaborative } \\ \text { F } & \text { Fahrenheit } \\ \text { FEA } & \text { finite element analysis } \\ \mathrm{ft} & \text { feet } \\ \mathrm{ft}^{2} & \text { square foot } \\ \mathrm{h} & \text { hour } \\ \mathrm{HDT} & \text { heat distortion temperature } \\ \text { IECC } & \text { International Energy Conservation Code } \\ \text { IGU } & \text { insulating glass unit } \\ \text { in. } & \text { inch } \\ \text { in. Hg } & \text { inch of mercury } \\ \text { IR } & \text { infrared } \\ \text { kPa } & \text { kilopascal } \\ \text { L } & \text { length } \\ \text { LBNL } & \text { Lawrence Berkeley National Laboratory } \\ \text { low-e } & \text { low-emissivity } \\ \mathrm{m} & \text { meter } \\ \mathrm{m}^{2} & \text { square meter } \\ \mu \mathrm{m} & \text { micrometer } \\ \mathrm{mm} & \text { millimeter } \\ \mathrm{MPa} & \text { megapascal } \\ \mathrm{NFRC} & \text { National Fenestration Rating Council } \\ \mathrm{PIB} & \text { polyisobutylene } \\ \text { psi } & \text { pound per square inch } \\ \mathrm{PVC} & \text { polyvinyl chloride } \\ \text { SHGC } & \text { solar heat gain coefficient } \\ \text { sq ft } & \text { square foot } \\ \mathrm{U} . S . & \text { United States } \\ \mathrm{USDA} & \text { United States Department } \\ \text { of Agriculture } & \\ \text { W } & \text { watt } \\ & \end{array}$

